\title{
Biological and microbial activity in biological soil crusts from the Tabernas desert, a sub-arid zone in SE Spain
}

\author{
Isabel Miralles ${ }^{\text {, }}$ Francisco Domingo a , Elena García-Campos ${ }^{\text {, }}$, \\ Carmen Trasar-Cepeda ${ }^{b^{*}}$, M. Carmen Leirós ${ }^{c}$, Fernando Gil-Sotres ${ }^{c}$ \\ ${ }^{a}$ Departamento de Desertificación y Geoecología, EEZA-CSIC, E-04230 La Cañada de San \\ Urbano, Almería, Spain; ${ }^{b}$ Departamento de Bioquímica del Suelo, IIAG-CSIC, Apartado 122, E- \\ 15780 Santiago de Compostela, Spain, and ${ }^{c}$ Departamento de Edafología y Química Agrícola, \\ Grupo de Evaluación de la Calidad del Suelo, Unidad Asociada CSIC, Facultad de Farmacia, \\ Universidad de Santiago de Compostela, E-15782 Santiago de Compostela, Spain. \\ * corresponding author
}

\begin{abstract}
The ecology and functional role of biological soil crusts (BSCs) in arid and semi-arid zones have been extremely well studied. However, little is known about the biochemical properties related to the number and activity of the microbiota that form the crusts, even though information about these properties is very important for understanding many of the processes that affect the formations. In this study, several properties related to the activity and number of microorganisms (biomass-C, basal respiration, dehydrogenase activity and nitrogen mineralization potential) were determined at different depths (crusts, $0-0.5 \mathrm{~cm}$; middle, $0.5-3 \mathrm{~cm}$ and deep, $3-5 \mathrm{~cm}$ layers) in two types of crusts (predominated by cyanobacteria and by lichens) in the Tabernas desert (Almeria, SE Spain). The absolute values of the above-mentioned properties and the values expressed relative to the total organic carbon (TOC) content were both much higher in the crust layers than in the surface horizons of soils under Mediterranean or Atlantic climates. A large part of the TOC in the BSCs was contained in the microbiota and another large part was readily metabolized during incubation of the crusts for 10 days at $25^{\circ} \mathrm{C}$. The net nitrogen mineralization rate was also high, and ammonification predominated in the crust layers, whereas nitrification predominated in the middle and deep layers. In all types of BSCs, the microbiota colonized the deep layers, although with greater intensity in the lichen-dominated BSCs than in the cyanobacterial BSCs. The results also indicate that hydrolytic enzymes are not stabilized on soil colloids and their activity depends only on the active microbiota.
\end{abstract}

Key words: Microbial biomass; Soil respiration; Dehydrogenase activity; Soil nitrogen mineralization; Lichens; Cyanobacteria.

\section{Introduction}


There has been a great deal of interest in studying biological soil crusts (BSCs) in recent years, which has led to the publication of diverse articles and books on the topic. The interest arose in light of the important role and multiple functions that BSCs have in arid and semi-arid environments (Bowker at al., 2010). Fixation of atmospheric $\mathrm{N}$ and $\mathrm{C}$ in soil is one of the important roles of BSCs. Thus, different studies have reported fixation rates of between 0.02 and $100 \mathrm{~kg} \mathrm{ha}^{-1}$ year $^{-1}$ for nitrogen (Skujins and Klubek, 1978; Veluci et al., 2006) and of between 4 and $370 \mathrm{~kg} \mathrm{ha}^{-1}$ year $^{-1}$ for carbon (Evans and Lange, 2003; Housman et al., 2006). Harper and Belnap (2001) also demonstrated that BSCs are capable of modifying nutrient availability to favour the establishment of biogeochemical cycles and the occupation of space by vascular plants. Several authors have also investigated the influence of BSCs on the hydrological cycle; some studies have demonstrated the role of BSCs in redistributing precipitation between infiltration and run-off (Malam Issa et al., 1999; Miralles et al., 2011), and others have demonstrated the protective effect of BSCs against erosion (Chaudhary et al., 2009). The latter effect is not only attributed to modification of the hydrological cycle by BSCs, but also to the production of extracellular polysaccharides and to the presence in BSCs of filamentous microbes (Fletcher and Martin, 1948; Bates and Garcia-Pichel, 2009). As regards the biological component of BSCs, the diversity of individual types of microorganisms that form the crusts is well documented (Anderson et al., 1982), and it is well known that BSCs contain both cyanobacteria and conspicuous eukaryotic constituents (such as bryophytes, liverworts and lichens). Fletcher and Martin (1948) suggested that BSCs may contain free-living microfungi that do not form lichens (non-lichenized fungi); these individuals are now considered, along with bacteria, archaea and algae, as common constituents of BSCs (Bowker et al., 2010), although they are less diverse and contribute much less biomass than their bacterial counterparts (Bates and Garcia-Pichel, 2009). The interactions between BSCs and other organisms such as vascular plants and their symbiotic fungi, as well as decomposer fungi and prokaryotes have also been the specific object of study (Defalco et al., 2001). At present, there is great interest in BSCs because of their role as accumulators of atmospheric $\mathrm{C}$, and therefore the possibility that large areas of arid and sub-arid regions in the world (approximately 33\% of the terrestrial surface of the earth: UNESCO, 1977) could act as $\mathrm{CO}_{2}$ sinks (Conant et al., 2004; Thomas et al., 2011). In this respect, current research is concerned with determining the changes in $\mathrm{CO}_{2}$ fluxes in $\mathrm{BSCs}$ degraded by human activity (Housman et al., 2006) and with exploring how the carbon cycle in BSCs may be affected by climate change (Grote et al., 2010).

Soil respiration, which involves the emission of $\mathrm{CO}_{2}$ during the decomposition of organic matter carried out by the metabolic activity of the plant roots and soil microorganisms, is a fundamental process in the carbon cycle (Fernandez et al., 2006) and represents the main pathway whereby carbon fixed by the soil is returned to the atmosphere (Schimel, 1995). Most studies on respiration in BSCs have been conducted under field conditions by the measurement of $\mathrm{CO}_{2}$ flows, in which more importance is given to respiration in the uppermost layers (usually the upper few millimetres) of these formations than to respiration in the deeper layers (Thomas et al., 2011). However, although most of the colonizing microorganisms are present in the upper layers, vertical stratification takes place in BSCs (Garcia-Pichel and Pringault, 2001), so that measurement of $\mathrm{CO}_{2}$ flows provides little information about the total metabolic activity in the BSCs. 
One way of mitigating the scarcity of information is by carrying out laboratory studies in which properties related to the metabolic activity of the microbiota are determined in the different layers of the BSCs. However, although numerous studies of this type have been conducted with mesic soils, they are relatively scarce in BSCs from arid and sub-arid zones (Fernandez et al., 2006). This is surprising considering that there are many simple reliable analytical techniques that could be used to evaluate properties related to the activity and abundance of the microorganisms comprising BSCs ("general biochemical parameters", Nannipieri et al., 1995). Such properties include biomass-C (simple estimation of the size of the microbial population), dehydrogenase activity, basal respiration or $\mathrm{CO}_{2}$ emitted (both properties related to the metabolic activity of the microbiota) and organic nitrogen mineralization (a measure of the capacity of microorganisms to generate inorganic forms of nitrogen by decomposition of organic remains).

Numerous studies of BSCs have been carried out in the Tabernas desert (Almería, SE Spain), which is characterised by a semi-arid climate. Different aspects of BSCs have been investigated in relation to erosion risk, hydrology, fertility, enzymatic activity, ecology and functional roles (Cantón et al., 2001; Lázaro et al., 2008, Miralles et al., 2012a).

One of the above-mentioned studies (Miralles et al., 2012a) demonstrated that hydrolytic enzyme activity occurs in the crust layer $(0-0.5 \mathrm{~cm})$ and in the middle $(0.5-3 \mathrm{~cm})$ and deep layers $(3-5 \mathrm{~cm})$ of the BSCs. In the present study, the general biochemical parameters were characterized in the same samples as in the previous study, with the aim of determining if the biochemical properties related to the abundance and activity of microorganisms are expressed throughout all layers of the BSCs and also if the enzyme activity is related to the presence of active organisms. The overall aim was to obtain basic information about the metabolic capacity of crusts, which may be used in posterior evaluation of whether similar biological soil crusts act as $\mathrm{CO}_{2}$ sources or sinks in sub-arid climates.

\section{Material and Methods}

\subsection{Site description}

The study was conducted at an experimental site (El Cautivo) located in the NeogeneQuaternary Tabernas depression, in the province of Almería, SE Spain. The geological, physiographical, pedological and climatic characteristics of the zone are described elsewhere (Miralles et al., 2012a). In brief, the basin is mainly filled with Neogene marine sediments, most of which are gypsum mudstones and calcaric sandstones. The climate is semi-arid thermoMediterranean (the average annual temperature is $17.9^{\circ} \mathrm{C}$ and the mean annual rainfall is 235 $\mathrm{mm}$, most of which falls in winter). The main types of soil at the site are Epileptic and Endoleptic Leptosols, Calcaric Regosols and Eutric Gypsisols (ISSS Working Group R.B., 1998). The soil texture is silty loam, and the mean percentages of sand, silt and clay under BSCs are $29 \pm 5,59 \pm 6$ and 12 \pm 4 , respectively; the soil $\mathrm{pH}$ (in water) ranges from 6.7 to 8.7 , and the calcium carbonate equivalent ranges from $11 \%$ to 30\% (Miralles et al., 2012a). The landscape of the study area comprises a mosaic of zones with vascular plants, BSCs and bare substrate (surface disaggregated geological substrate). The BSCs represent more than $45 \%$ of the surface cover. Several studies have been carried out at the site to investigate aspects such as 
geomorphology, hydrology and erosion, and a very detailed description of the area is available elsewhere (Cantón et al., 2001; Lázaro et al., 2008, amongst others).

\subsection{Types of biological soil crusts and field sampling.}

Lázaro et al. (2008) described three successional stages of BSCs in the study area, by considering the predominant type of microorganism and the crust colour as indicators. The stages are as follows: 1) an early successional stage constituted by cyanobacteria-dominated BSC (CYANO), which often includes diverse species such as Nostoc spp., a relatively high proportion of squamulose lichen species and Microcoleus spp. sheath material; 2) a second successional stage constituted by lichen BSC predominated by Diploschistes diacapsis (Ach.) Lumbsch (DIPLOS); and 3) the final development stage constituted by lichen BSC predominated by Lepraria crassissima (Hue.) Lettau (LEPRA). A detailed description of the biological constituents of each type of crust is provided elsewhere (Miralles et al., 2012a).

Each of the above-mentioned types of BSC was sampled at three closely located sites, in January 2011 (i.e. during the rainy season). At each site, a composite sample was obtained by mixing 1015 subsamples (each representative of an area about 0.1 ha) in the field. The upper few millimetres of the surface $(0-0.5 \mathrm{~cm})$ were extracted (crust layer) from the DIPLOS and LEPRA BSCs. Once the Crust layer was isolated, samples were also collected from two different depths (middle layer: 0.5-3 cm and deep layer: $3-5 \mathrm{~cm}$ ). In the CYANO BSCs, which are the least well developed, only two layers were sampled (crust layer: $0-0.5 \mathrm{~cm}$, and deep layer: the $0.5-3 \mathrm{~cm}$ immediately below the crust layer). The bare substrate $(0-0.5 \mathrm{~cm})$ was also sampled in surrounding areas (10-15 subsamples were obtained as described above).

The samples were placed in isothermal bags and transported to the laboratory where they were sieved $(<4 \mathrm{~mm})$ and stored at $4{ }^{\circ} \mathrm{C}$ until the biochemical analyses were carried out, in all cases within 15 days of collection. The moisture content was determined by gravimetry in an aliquot of moist sample dried at $105{ }^{\circ} \mathrm{C}$ for $24 \mathrm{~h}$. Another portion of each sample was air-dried before carrying out general analyses.

\subsection{Analysis of general properties}

The methods described by Guitián and Carballas (1976) were used to determine the following soil properties: $\mathrm{pH}$ in water (1:2.5, soil:water ratio), total organic carbon (TOC) content (by wet oxidation with potassium dichromate oxidation and prior elimination of carbonates), and total nitrogen (TN) content (by Kjeldahl digestion). The results obtained for these properties are summarised in Table 1, and as they are described in detail in a previous study (Miralles et al., 2012a) they will not be discussed here.

\subsection{Analysis of general biochemical parameters}

Microbial biomass-C (Biomass-C), an easily obtained measure of the size of the microbial population including free-living fungi (Jenkinson, 1976), was determined by the chloroform fumigation extraction method, with $0.5 \mathrm{M} \mathrm{K}_{2} \mathrm{SO}_{4}$ as extractant, at a soil:extractant ratio of 1:4 (Vance et al., 1987). The organic carbon in the extracts was estimated by potassium dichromate 
oxidation of an aliquot dried at $60{ }^{\circ} \mathrm{C}$. The difference in the $\mathrm{C}$ content of the extracts from fumigated and unfumigated samples was converted to microbial biomass $\mathrm{C}$ by dividing the value obtained by a factor $\left(K_{c}\right)$ of 0.45 (Vance et al., 1987). Triplicate samples of each layer were analysed, and each measurement in the fumigated and non fumigated extracts was carried out in triplicate, so that the individual values in each case are mean values from 9 determinations. Results are expressed as $\mathrm{mg} \mathrm{C} \mathrm{kg}^{-1}$ of oven-dried soil.

Basal soil respiration (a measure of the activity of soil microorganisms) was determined in the dark (dark respiration) by static incubation (Guitián and Carballas, 1976): triplicate aliquots of each BSC layer were incubated in the dark in closed Mason jars for 10 days at $25{ }^{\circ} \mathrm{C}$ and at field moisture. A vial with $\mathrm{NaOH}$ was placed in each jar to capture the $\mathrm{CO}_{2}$ emitted. The vial containing $\mathrm{NaOH}$ was replaced daily during the first ten days and then every 3-4 days. The $\mathrm{CO}_{2}$ emitted was determined by titration of the remaining $\mathrm{NaOH}$ in the vials with $\mathrm{HCl}$, after prior precipitation (with barium chloride) of the carbonates formed (Guitián and Carballas 1976). The $\mathrm{CO}_{2}$ titrations were carried out in triplicate throughout the incubation, so that the individual values in each case are mean values from 9 determinations. Results are expressed as $\mathrm{mg} \mathrm{CO}_{2}-\mathrm{C}$ emitted $\mathrm{kg}^{-1}$ of oven-dried soil $10 \mathrm{~d}^{-1}$.

The inorganic forms of $\mathrm{N}$ present before and after the above indicated incubation were extracted with $2 \mathrm{M} \mathrm{KCl}$ (ratio 1:10, 30 minutes) and determined by semi-micro Kjeldahl distillation (Bremner, 1965). The inorganic $\mathrm{N}$ produced by mineralization of the organic forms of nitrogen in the BSC layers (net mineralized N) was calculated as the difference between these amounts. For each sample, extractions and distillations were carried out in triplicate, so that the individual values in each case are mean values from 9 determinations. Results are expressed as mg inorganic $\mathrm{N}$ (Total inorganic, $\mathrm{NO}_{3}{ }^{-} \mathrm{N}$ or $\mathrm{NH}_{4}{ }^{+}-\mathrm{N}$ ) $\mathrm{kg}^{-1}$ of oven-dried soil.

Dehydrogenase activity (an intracellular enzyme present only in active cells) was determined by a modification of the method of von Mersi and Schinner (1991) described by Camiña et al. (1998). Briefly, the activity was determined after incubating the iodonitrotetrazolium violet (INT) substrate with $1 \mathrm{M}$ TRIS-HCl buffer $\mathrm{pH} 7.5$ for 1 hour. The iodonitrotetrazolium formazan (INTF) produced was extracted with a 1:1 (v:v) mixture of ethanol and dimethylformamide, and measured spectrophotometrically at $490 \mathrm{~nm}$. The activity was quantified by reference to a calibration curve constructed with data obtained by incubating INTF standards with soil under the same conditions described above, and is expressed in $\mu$ mol INTF $g^{-1} \mathrm{~h}^{-1}$.

\subsection{Statistical analysis}

For each layer of each type of BSC, all data for the same property were averaged to produce a mean value to avoid pseudo-replication (Mager, 2010). Statistical analyses (means, standard deviations, two-sample $t$-tests of significance between means) were performed with Statistica 6.0 (StatSoft ${ }^{\circledR}$ ) for Windows.

\section{Results}

The values for Biomass-C, basal respiration and dehydrogenase activity were close to zero in the bare substrate (Table 2). In all of the BSCs, the Biomass-C decreased significantly $(P<0.01)$ from the crust layer to the deep layer, and the values were much lower in the middle and deep 
layers than in the crust layers, and the differences were significant in all cases (Table 2). In the crust layers, Biomass-C increased in the order CYANO < DIPLOS < LEPRA, whereas in the middle and deep layers, the Biomass-C content was higher in DIPLOS than in LEPRA, although the difference was not significant (Table 2). The same pattern was observed for the dehydrogenase activity, and, as with the Biomass-C, the values in the crust layers of DIPLOS and LEPRA were very similar (Table 2). The value of the ratio between dehydrogenase activity and Biomass-C was lowest in the crust layer of CYANO and highest in the crust layer of DIPLOS, and in all cases increased with depth, although the difference was only significant for CYANO (Table 2).

Basal respiration, measured as $\mathrm{CO}_{2}-\mathrm{C}$ emitted in the dark (dark respiration), increased significantly $(P<0.01)$ from the deep layer to the surface, as also observed for the other properties (Table 2). Basal respiration was highest in the crust layer of DIPLOS and lowest in the crust layer of CYANO; the value in the latter was significantly lower $(P<0.01)$ than the values in the crust layers of the other two BSCs. The high respiration rates observed in the crust layer of DIPLOS may be due to the growth of fungal hyphae during the incubation, and suggest the presence of free-living fungi.

The same pattern (minimum value in CYANO, maximum value in DIPLOS) was observed for the respiration coefficients (\% $\mathrm{CO}_{2}-\mathrm{C}$ emitted/TOC) and metabolic coefficient, or $q \mathrm{CO}_{2}$ $\left(\mathrm{CO}_{2}-\mathrm{C}\right.$ emitted in a unit of time per unit of Biomass-C). The $q \mathrm{CO}_{2}$ value obtained for the crust layer of CYANO was close to 2, but was much higher in the crust layers of the BSCs predominated by lichens, up to 9.6 in DIPLOS and up to 6.3 in LEPRA (Fig. 1). The respiratory coefficient reached values of $7.2 \%$ in the crust layer of CYANO, $10.6 \%$ in LEPRA and $12.2 \%$ in DIPLOS, and the differences between the cyanobacterial and lichen BSCs were significant $(P<0.01)$. The values of the microbial coefficient (\% Biomass-C/TOC) were very high in the crust layers (16\%) of CYANO and decreased significantly (by more than half) in DIPLOS and LEPRAS, with the lowest value in DIPLOS (Fig. 1).

The total inorganic nitrogen initially present increased in all BSCs in the order deep layer < middle layer < crust layer, although the contents in the crust and deep layers of the CYANO were almost identical (Table 3). Furthermore, in all of the BSCs, the $\mathrm{NH}_{4}{ }^{+}-\mathrm{N}$ increased towards the surface, whereas the contents of $\mathrm{NO}_{3}{ }^{-} \mathrm{N}$ were highest in the middle and deep layers (Table 3). Independently of the absolute values, the percentage of $\mathrm{NH}_{4}{ }^{+}-\mathrm{N}$ in the crust layers was always higher than $40 \%$ of the initial inorganic nitrogen, and the percentage increased gradually and significantly $(P<0.01)$ in the order CYANO < DIPLOS < LEPRA. As in the bare substrate, the $\mathrm{NO}_{3}{ }^{-} \mathrm{N}$ predominated over $\mathrm{NH}_{4}{ }^{+}-\mathrm{N}$ in the middle and deep layers (Fig. 2).

Net nitrogen mineralization was almost zero in both the bare substrate and the deep layer of the CYANO BSCs (Table 3). In the other layers studied, the net nitrogen mineralization rates were high and the highest values were observed in the crust layers (Table 3). The maximum net mineralization in the crust layers occurred in CYANO and decreased in the order DIPLOS > LEPRA, although the differences between the three layers were not significant $(P<0.01)$. In the crust layers, the mineralization mainly produced $\mathrm{NH}_{4}{ }^{+}-\mathrm{N}$, whereas in the middle and deep layers the mineralization produced $\mathrm{NO}_{3}{ }^{-} \mathrm{N}$ almost exclusively (Fig 2). Furthermore, the amount of $\mathrm{NO}_{3}{ }^{-} \mathrm{N}$ in the crust layers increased gradually in the order CYANO < DIPLOS < LEPRA, and the proportion of this form of nitrogen was always lower than that of $\mathrm{NH}_{4}{ }^{+}-\mathrm{N}$ (Fig 2). 


\section{Discussion}

Biomass- $\mathrm{C}, \mathrm{CO}_{2}-\mathrm{C}$ emitted and dehydrogenase activity were extremely high in the crust layers of all BSCs, even higher than in the Ah horizons of temperate forest soils with mean TOC contents above $10 \%$ (Table 4$)$. The microbial coefficient (\% Biomass-C/TOC) and the respiratory coefficient $\left(\% \mathrm{CO}_{2}-\mathrm{C} / \mathrm{TOC}\right)$ were significantly higher $(P<0.01)$ in the BSCs than in the other soils used for comparison (Table 4). The values of the microbial coefficient were particularly high, and showed that between 5 and $16.5 \%$ of the TOC content in the crust layers was attributed to active organisms. These levels are similar to those reported by other authors for BSCs (Thomas and Dougill, 2007; Wang et al., 2007), and confirm the suggestion that BSCS support extraordinarily high populations of microorganisms, at least in the crust layers. The microbial coefficients may actually be even higher than observed, as the microbial biomass may have been underestimated as a result of the growth of free-living fungi during the incubation, and therefore the $K_{c}$ value used to transform the $\mathrm{C}$ flush into biomass $(0.45)$ may have been too high (Hurst and Wagner, 1969; Jenkinson, 1976). Nonetheless, the high values of Biomass-C per unit of TOC are consistent with the high values of dehydrogenase activity per unit of TOC, which are also much higher than in other soils (Table 4). As the dehydrogenase activity reflects the capacity to transport electrons generated in intracellular metabolic processes, high values of dehydrogenase/TOC signify a high metabolic power per unit of organic carbon fixed. All of these data reflect that the BSCs studied contain large number of microorganisms with a high oxidative capacity. As expected from these observations, the respiratory coefficients were also high and reflected that between 7 and $12 \%$ of the TOC may be readily metabolized within 10 days. This indicates a high metabolic capacity, which is also characteristic of BSCs (Conant et al., 2004). The high metabolic capacity can be explained by the presence of large amounts of simple compounds excreted by cyanobacteria and other autotrophic organisms, which accumulate and form a large part of the TOC (Thomas et al., 2011). The activation energies of such compounds, which contain exudates and products released from the cells of dead organisms (Luo and Zhou, 2006), are much lower than those of mixtures of materials that make up the organic matter of more developed soils, and they are therefore extremely labile and metabolizable. Nonetheless, it must be taken into account that the respiratory coefficients were obtained under conditions of controlled constant moisture (they were not subjected to desiccation during this period) and darkness, so that photosynthetic activity was inhibited (Grote et al., 2010). Therefore, the values do not reflect field conditions, as under real conditions the high temperatures would dry up the rainwater, thereby reducing the microbial activity and, therefore, the respiration (Thomas et al., 2011). Otherwise, carbon would not accumulate under the crusts, as almost all of the $\mathrm{C}$ excreted would be used up in metabolic processes (Conant et al., 2004).

There are two apparently contradictory findings in the study. First, the $q \mathrm{CO}_{2}$ values (metabolic coefficient, a coefficient that expresses the metabolic capacity per unit of Biomass-C per unit of time) are clearly higher in the BSCs (except in CYANO in which the values can be considered physiologically normal) than in other soils (Table 4). Although this may suggest that the lichen populations are highly stressed because they display high levels of microbial respiration throughout the incubation period (Anderson and Domsch, 1985) in response to the optimal conditions of moisture and temperature during the incubation, it may also reflect the 
respiration generated by fungi that have grown during the incubation period. The high values of $q \mathrm{CO}_{2}$ may also be explained by the probable underestimation of microbial biomass due to the use of an inappropriate $K_{c}$ value, as already indicated. Second, the values of the ratio between dehydrogenase activity and Biomass-C are clearly lower in the BSCs than in the other soils used for comparison (Table 4), suggesting a low concentration of dehydrogenase activity in the organisms constituting the BSCs, which is not very consistent with the high respiratory activity observed. The low dehydrogenase activity per unit of biomass may reflect the predominance in these BSCs of a very simple type of metabolism that leads to the degradation of structurally simple compounds (basically carbohydrates), which does not require a high oxidative potential (Mager, 2010).

In almost all cases, the incubation generated net mineralization of the organic nitrogen (Table 3 ), and the percentage distribution of the different species of mineralized inorganic $\mathrm{N}$ showed that $\mathrm{NH}_{4}{ }^{+}-\mathrm{N}$ predominated in the crust layer and $\mathrm{NO}_{3}{ }^{-} \mathrm{N}$ in the deeper layers (Fig. 2). The different distribution of inorganic $\mathrm{N}$ forms is similar to that indicated by other authors (Johnson et al., 2005; Delgado-Baquerizo et al., 2010), and although it obviously suggests a predominance of ammonification in the crust layer and of nitrification in the deeper layers, other explanations have been suggested. For example, some authors suggest that the predominance of ammonium may be due to the preferential consumption of nitrate by surface microorganisms (CastilloMonroy et al., 2010), whereas others suggest loss of nitrate via denitrification processes (Johnson et al., 2007) or inhibition of nitrification as a result of the production of allelopathic substances by BSCs (Fahselt, 1994). The predominance of ammonification processes in the crust layer has been interpreted as an economic strategy to avoid the high consumption of ATP during nitrification or during the biosynthesis of proteins throughout the intracellular reduction of nitrate to ammonium (Schlesinger, 1996). It has also been suggested that this may be due to a different distribution and abundance of ammonifying organisms (highly abundant and concentrated in the Crust layers) and of nitrifiers (less abundant) (Garcia-Pichel and Pringault, 2001; Johnson et al., 2005). Whatever the reason, it is clear that the crust layer is different from the other layers, although it appears that the difference decreases as ecological substitution progresses, because the crust layer of LEPRA is the least ammonifying (in percentage terms) and the crust layer of CYANO the most ammonifying. The intense ammonification observed in the crust dominated by cyanobacteria may be related to the need for cyanobacteria to release both inorganic and organic (with readily mineralizable amine and amide groups) nitrogenous compounds to favour the uptake of $\mathrm{N}$ by non $\mathrm{N}$-fixing microorganisms and facilitate the symbiotic relationships with fungi (Belnap 2002).

Biological activity was observed in all layers of all of the BSCs analysed, unlike in the bare substrate, in which activity was almost non-existent (Table 2), and the values of the biochemical properties decreased strongly from the crust to the deep layers, showing clear stratification of the colonizers. Such stratification has been described in previous studies, and it is generally considered that BSCs consist of an intensely populated (and therefore biologically very active) layer of a few millimetres thick, and a less populated lower layer (Garcia-Pichel et al., 2003). Thus the Crust layer coincides with the photic zone (mainly colonized by autotrophic organisms), characterized by high luminosity, large variations in temperature and a lack of moisture in dry seasons (Mager, 2010), whereas the lower layer is predominated by heterotrophic 
organisms due to the lack of light. As regards the depth of the crust (i.e. the colonization at depth), it is clear that the lichen-dominated BSCs (to a greater extent in DIPLOS than in LEPRA) are better colonizers at depth than the cyanobacterial BSCs, because the absolute values of the properties studied are of similar magnitude in the deep layer of the lichen BSCs $(3-5 \mathrm{~cm})$ and in the deep layer of the cyanobacterial BSCs $(0.5-3 \mathrm{~cm})$, despite the different depth of sampling. However, if the stratification ratio (i.e. the percentage value of a property at any level relative to the value in the crust layer) is considered as an indicator of the colonization at depth, then all types of BSCs are similar, although the increases in respiration and dehydrogenase activity appear to be greater at depth under the cyanobacterial BSCs than under the lichendominated BSCs (Fig. 3). In contrast, the greatest enrichment of Biomass-C occurred in the middle and deep layers of DIPLOS (Fig. 3). Interestingly, the dehydrogenase/biomass-C ratio, which indicates the oxidative capacity per unit of biomass, increased at depth in all types of BSCs, in the order CYANO < DIPLOS < LEPRA (Table 2). This variation may indicate that as ecological substitution takes place (from cyanobacterial crusts to crusts formed by lichens), the microorganisms in the deeper layers display higher dehydrogenase activity than those in the Crust layers, although the total activity in these layers will decrease gradually (Table 2).

Nonetheless, the differences between BSCs are probably not very important from the point of view of the overall metabolic capacity of the BSCs, as the values of dehydrogenase activity and biomass- $\mathrm{C}$ were strongly correlated with those of the activity of some of the hydrolase enzymes indicated in a previous study (Miralles et al. 2012a), considering all of the BSCs and levels analyzed. These correlations suggest that oxidative and hydrolytic processes are almost perfectly coupled in all layers, independently of the colonizer (Table 5) or, in other words, that the cell metabolism is perfectly coupled to the extracellular decomposition of organic remains. Moreover, the regression lines pass very close to the origin (Fig. 4), indicating that almost all of the hydrolytic activity depends on the active microbiota (West et al., 1988; Nannipieri et al., 1996) and that stabilization of the hydrolases on the BSC components has therefore still not occurred or is only incipient. These results are in contrast with those reported by other authors who have suggested the presence in BSCs of a pool of enzymes stabilized on inorganic colloidal components (Collins et al., 2008; Stursova and Sinsabaugh, 2008; Sinsabaugh, 2010). The lack of stabilized hydrolytic enzyme activity, which is independent of the active organisms, may be attributed, in the crusts under study here, to a lack of humic substances (Miralles et al., 2012b), which would act as structural supports for the stabilization of hydrolytic enzymes. This, in turn, would reflect the scarce edaphic development generated by the presence of cyanobacteria and lichens on the bare disaggregated geological substrate.

\section{Conclusions}

The general biochemical data confirm the high abundance of very active organisms in BSCs, with much higher microbial and respiratory coefficients than in other types of soils.

There is clear stratification of colonizers in the BSCs, reaching greater depths (and therefore reflecting a greater abundance of heterotrophs) in the lichen-dominated BSCs than in the cyanobacterial BSCs, although the density of active microorganisms in the deeper layers relative to the crust layer was similar in all types of BSCs. The stratification is also reflected in the 
nitrogen dynamics, with a predominance of ammonification in the crust layer and a predominance of nitrification in the deeper layers.

The hydrolase-type enzyme activity in the BSCs studied is clearly dependent to the presence of active microorganisms, i.e. extracellular stabilization of the hydrolytic enzyme activity had not occurred. This confirms the pioneering nature of these formations and demonstrates their fragility, as any event affecting the survival of the microorganisms present will affect the development of the processes of transformation of organic remains.

The high respiratory coefficients observed suggest that a large part of the $\mathrm{C}$ present may be lost within a short time. However, it must be remembered that the study was carried out with samples under optimal conditions of moisture, and therefore the crusts were in a state of maximal activity. Further investigation is required to determine the environmental conditions under which such high values are maintained, how the laboratory data can be applied to field conditions, and the extent to which photosynthetic processes within BSCs decrease the high mineralization capacity. This type of information is essential in order to understand and favour mechanisms of accumulation of organic $\mathrm{C}$ in BSC and the role of these formations as atmospheric $\mathrm{CO}_{2}$ sinks.

\section{Acknowledgements:}

The authors thank Ana I. Iglesias-Tojo for assistance in carrying out the analyses. The authors are grateful for support from the GEOCARBO project (Ref: RNM-3721), funded by the regional government Junta de Andalucía and the Fellowships Juan de la Cierva 2008-39669 and CARBORAD (CGL2011-27493) and CGL2008-01992/BTE funded by the Ministerio de España de Ciencia e Innovación, including funds of the European Q8 Union European Regional Development Fund.

\section{References}

Anderson, I.C., Harper, K.T., Rushforth, S.R., 1982. Recovery of cryptogamic soil crusts from grazing on Utah winter ranges. Journal of Range Management 35, 355-359.

Anderson, T.H., Domsch, K.H., 1985. Determination of the ecophysiological maintenance carbon requirements of soil microorganisms in a dormant state. Biology and Fertility of Soils 1, 81-89.

Bates, S.T., Garcia-Pichel, F.T., 2009. A culture-independent study of free-living fungi in biological soil crusts of the Colorado Plateau. Their diversity and relative contribution to microbial biomass. Environmental Microbiology 11, 56-67.

Belnap, J., 2002. Nitrogen fixation in biological soil crusts from southeast Utah, USA. Biology and Fertility of Soils 35, 128-135.

Bowker, M.A., Maestre, F.T., Escolar, C., 2010. Biological crusts as a model system for examining the biodiversity-ecosystem function relationship in soils. Soil Biology \& Biochemistry 42, 405-417.

Bremner, J.M., 1965. Inorganic forms of nitrogen. In: Black, C.A., Evans, D.D., White, J.L., Ensminger, L.E., Clark, F.E. (Eds.), Methods of Soil Analysis, Part 2, Microbiological and 
Biochemical Properties. Academy Science of Agriculture - Soil Science Society of America, Madison, pp. 1179-1237.

Camiña, F., Trasar-Cepeda, C., Gil-Sotres, F., Leirós, M.C., 1998. Measurement of dehydrogenase activity in acid soils rich in organic matter. Soil Biology \& Biochemistry 30, 1005-1011.

Cantón, Y., Domingo, F., Solé-Benet, A., Puigdefábregas, J., 2001. Hydrological and erosion response of a badlands system in semiarid SE Spain. Journal of Hydrology 252, 65-84.

Castillo-Monroy, A.P., Maestre, F.T., Delgado-Baquerizo, M., Gallardo, A., 2010. Biological soil crusts modulate nitrogen availability in semi-arid ecosystems: insights from a Mediterranean grassland. Plant and Soil 333, 21-34.

Chaudhary, V.B., Bowker, M.A., O’dell, T.E., Grace, J.B., Redman, A.E., Rilling, M.C., Johnson, N.C., 2009. Untangling the biological contributions to soil stability in semiarid shrublands. Ecological Applications 19, 110-122.

Collins, S.L., Sinsabaugh, R.L., Crenshaw, Ch., Green, L., Porras-Alfaro, A., Stursova, M., Zeglin, L.H., 2008. Pulse dynamics and microbial processes in aridland ecosystems. Journal of Ecology 96, 413-420.

Conant, R.T., Dalla-Betta, P., Klopatek, C.C., Klopatek, J.M., 2004. Controls on soil respiration in semiarid soils. Soil Biology \& Biochemistry 36, 945-951.

DeFalco, L.A., Detling, J.K., Tracy, C.R., Warren, S.D., 2001. Physiological variation among native and exotic winter annual plants associated with microbiotic crusts in the Mojave Desert. Plant and Soil 234, 1-14.

Delgado-Baquerizo, M., Castillo-Monroy, A.P., Maestre, F.T., Gallardo, A., 2010. Plants and biological soil crusts modulate the dominance of $\mathrm{N}$ forms in a semi-arid grassland. Soil Biology \& Biochemistry 42, 376-378.

Evans, R.D., Lange, O.L., 2003. Biological soil crusts and ecosystem nitrogen and carbon dynamics. In: Belnap, J., Lange, O.L. (Eds.), Biological Soil Crusts: Structure, Function and Management, vol. 150. Springer, Berlin, pp. 263-279.

Fahselt, D., 1994. Secondary biochemistry of lichens. Symbiosis 16, 117-165.

Fernandez, D.P., Neff, J.C., Belnap, J., Reynolds, R.L., 2006. Soil respiration in the cold desert environment of the Colorado Plateau (USA): abiotic regulators and thresholds. Biogeochemistry 78, 247-265.

Fletcher, J.E., Martin, W.P., 1948. Some effects of algae and molds in the rain-crust of desert soils. Ecology 29, 95-100.

Garcia-Pichel, F., Johnson, S.L., Youngkin, D., Belnap, J., 2003. Small-scale vertical distribution of bacterial biomass and diversity in biological soil crusts from arid-lands in the Colorado plateau. Microbial Ecology 46, 312-321.

Garcia-Pichel, F., Pringault, O., 2001. Cyanobacteria track water in desert soils. Nature 413, 380-281.

Grote, E.E., Belnap, J., Housman, D.C., Sparks, J.P., 2010. Carbon exchange in biological soil crust communities under differential temperatures and soil water contents: implications for global change. Global Change Biology 16, 2763-2774.

Guitián, F., Carballas, T., 1976. Técnicas de análisis de suelos. Pico Sacro Editorial, Santiago de Compostela. 
Harper, K., Belnap, J., 2001. The influence of biological soil crusts on mineral uptake by associated vascular plants. Journal of Arid Environments 47, 347-357.

Housman, D.C., Powers, H.H., Collins, A.D., Belnap, J., 2006. Carbon and nitrogen fixation differ between successional stages of biological soil crusts in the Colorado Plateau and Chihuahuan Desert. Journal of Arid Environments 66, 620-634.

Hurst, H.M., Wagner G.H., 1969. Decomposition of ${ }^{14} \mathrm{C}$-labelled cell wall and cytoplasmic fractions from hyaline and melanic fungi. Proceedings of Soil Science Society of America 33, 707-711.

ISSS Working Group R.B., 1998. World Reference Base for Soil Resources: Introduction. International Society of Soil Science, International Soil Reference and Information Centre and Food and Agriculture Organization of the United Nations. Acco, Leuven.

Jenkinson, D.S. 1976. The effects of biocidal treatments on metabolism in soil -IV. The decomposition of fumigated organisms in soil. Soil Biology \& Biochemistry 8, 203-208.

Johnson, S.L., Budinoff, Ch.R., Belnap, J., Garcia-Pichel, F., 2005. Relevance of ammonium oxidation within biological crust communities. Environmental Microbiology 7, 1-12.

Johnson, S.L., Neuer, S., Garcia-Pichel, F., 2007. Export of nitrogenous compounds due to incomplete cycling within biological soil crusts of arid lands. Environmental Microbiology 9, 680-689.

Lázaro, R., Cantón, Y., Solé-Benet, A., Bevan, J., Alexander, R., Sancho, L.G., Puigdefábregas, J., 2008. The influence of competition between lichen colonization and erosion on the evolution of soil surfaces in the Tabernas badlands (SE Spain) and its landscape effects. Geomorphology 102, 252-266.

Luo, Y., Zhou, X., 2006. Soil Respiration and the Environment. Academic Press, London.

Mager, D.M., 2010. Carbohydrates in cyanobacterial soil crusts as a source of carbon in the southwest Kalahari, Botswana. Soil Biology \& Biochemistry 42, 313-318.

Malam Issa, O., Trichet, J., Défarge, C., Couté, A., Valentin, C., 1999. Morphology and microstructure of microbiotic soil crusts on a Tiger bush sequence (Nigel, Sahel). Catena 37, 175-196.

Miralles, I., Cantón, Y., Solé-Benet, A. 2011. Two-dimensional porosity of crusted silty soils: indicators of soil quality in semiarid rangelands? Soil Science Society of America Journal 75, 1289-1301.

Miralles, I., Domingo, F., Cantón, Y., Trasar-Cepeda, C., Leirós, M.C., Gil-Sotres, F., $2012 a$. Hydrolase enzyme activities in a successional gradient of biological soil crusts in arid and semi-arid zones. Soil Biology \& Biochemistry 53, 124-132.

Miralles, I., Ortega, R., Sánchez, M., Trasar-Cepeda, C., Leirós, M.C., Gil-Sotres, F., 2007a. Biochemical activity in soils in a subdesert climate. Proceedings of The Third Internacional Conference: Enzymes in the Environment, Ecology, Activity, Applications, Viterbo, Italy, pp. 49.

Miralles, I., Ortega, R., Sánchez-Marañón, M., Leirós, M.C., Trasar-Cepeda, C., Gil-Sotres, F., 2007b. Biochemical properties of range and forest soils in Mediterranean mountain environments. Biology and Fertility of Soils 43, 721-729.

Miralles, I., van Wesemael, B., Cantón, Y., Chamizo, S., Ortega, R., Domingo, F., Almendros, G., 2012b. Surrogate descriptors of organic matter resilience in biological soil crusts from 
semiarid Mediterranean ecosystems. Geoderma (in press), doi: 10.1016/j.geoderma.2012.05.011.

Nannipieri, P., Landi, L., Badalucco, L., 1995. La capacità metabólica e la qualità del suolo. Agronomia 29, 312-316.

Nannipieri, P., Sastre, I., Landi, L., Lobo, M.C., Pietramellara, G., 1996. Determination of extracellular neutral phosphomonoesterase activity in soil. Soil Biology \& Biochemistry 28, 107-112.

Schimel, D.S., 1995. Terrestrial ecosystems and the carbon cycle. Global Change Biology 1, 7791.

Schlesinger, W.M., 1996. Biogeochemistry, an Analysis of Global Change. Academic Press, San Diego.

Sinsabaugh, R.L., 2010. Phenol oxidase, peroxidase and organic matter dynamics of soil. Soil Biology \& Biochemistry 42, 391-404.

Skujins, J., Klubek, B., 1978. Nitrogen fixation and denitrification in arid soil cryptogamic crust microenvironments. In: Krumbein, W.E. (Ed.) Environmental Biogeochemistry and Geomicrobiology, vol. 2. Ann Arbor Sciences Publishers, Ann Arbour, Michigan, pp. 543552.

Stursova, M., Sinsabaugh, R.L., 2008. Stabilization of oxidative enzymes in desert soil may limit organic matter accumulation. Soil Biology \& Biochemistry 40, 550-553.

Thomas, A.D., Dougill, A.J., 2007. Spatial and temporal distribution of cyanobacterial soil crusts in the Kalahari: implications for soil surface properties. Geomorphology 85, 17-29.

Thomas, A.D., Hoon, S.R., Dougill, A.J., 2011. Soil respiration at five sites along the Kalahari Transect: Effects of temperature, precipitation pulses and biological soil crust cover. Geoderma 167-168, 284-294.

Trasar-Cepeda, C., Leirós, C., Gil-Sotres, F., 2008. Hydrolythic enzyme activities in agricultural and forest soils. Some implications for their use as indicators of soil quality. Soil Biology \& Biochemistry 40, 2146-2155.

UNESCO, 1977. World Map of Arid Regions. United Nations Educational, Scientific and Cultural Organization, Paris.

Vance, E.D., Brookes, P.C., Jenkinson, D.S., 1987. An extraction method for measuring soil microbial biomass carbon. Soil Biology \& Biochemistry 19, 703-707.

Veluci, R.M, Neher, D.N., Weicht, Th.R., 2006. Nitrogen fixation and leaching of biological soil crust communities in mesic temperate soils. Microbial Ecology 51, 189-196.

von Mersi, W., Schinner, F., 1991. An improved and accurate method for determining the dehydrogenase activity of soil with iodonitrotetrazolium chloride. Biology and. Fertility of Soils 11, 216-220.

Wang, L., D’Odorico, P., Ringrose, S. Coetzee, S., Macko, S.A., 2007. Biogeochemistry of Kalahari sands. Journal of Arid Environments 71, 259-279.

West, A.W., Sparling, G.P., Speir, T.W., Wood, J.M., 1988. Comparison of microbial C, N-flush and ATP, and certain enzyme activities of different textured soils subject to gradual drying. Australian Journal of Soil Research 26, 217-229. 
Table 1. General properties of the samples studied. Different lower case letters indicate that values in the different layers under the same colonizing organisms are significantly different; different capital letters indicate that similar layers for different colonizers are significantly different $(P<0.01)$. The bare substrate is compared with the deepest layer analysed for each colonizing organism.

\begin{tabular}{lcccc}
\hline & pH water & TOC \% & TN \% & C/N \\
\hline $\begin{array}{l}\text { Bare substrate } \\
\text { CYANO }\end{array}$ & $8.15 \pm 0.06 a$ & $0.57 \pm 0.03 a$ & $0.10 \pm 0.00 a$ & $6.0 \pm 0.3 a$ \\
$\quad$ Crust layer & $A 7.68 \pm 0.01 a$ & $A 0.86 \pm 0.35 a$ & $A 0.15 \pm 0.03 a$ & $A 5.5 \pm 1.2 a$ \\
$\quad$ Deep layer & $B 8.12 \pm 0.16 a$ & $A 0.83 \pm 0.33 b$ & $B 0.08 \pm 0.02 a$ & $B 9.5 \pm 1.4 b$ \\
DIPLOS & & & & \\
$\quad$ Crust layer & $A 6.71 \pm 0.01 b$ & $A 4.28 \pm 0.96 b$ & $A 0.26 \pm 0.01 b$ & $B 6.2 \pm 3.0 a$ \\
$\quad$ Middle layer & $B 8.41 \pm 0.12 a$ & $B 1.17 \pm 0.19 a$ & $B 0.13 \pm 0.02 a$ & $B 9.4 \pm 2.5 a$ \\
$\quad$ Deep layer & $C 8.66 \pm 0.06 c$ & $C 0.79 \pm 0.07 b$ & $C 0.09 \pm 0.01 a$ & $B 8.5 \pm 0.6 b$ \\
LEPRA & & & & \\
$\quad$ Crust layer & $A 6.99 \pm 0.08 c$ & $A 3.86 \pm 0.24 b$ & $A 0.27 \pm 0.03 b$ & $A 14.5 \pm 1.0 b$ \\
$\quad$ Middle layer & $B 8.26 \pm 0.03 b$ & $B 1.24 \pm 0.18 a$ & $B 0.13 \pm 0.02 a$ & $B 9.3 \pm 0.4 a$ \\
$\quad$ Deep layer & $B 8.27 \pm 0.15 a$ & $C 0.85 \pm 0.01 b$ & $C 0.09 \pm 0.00 a$ & $B 9.0 \pm 0.2 b$ \\
\hline
\end{tabular}


Table 2. Values of different properties related to the size and activity of Biomass-C present in BSCs. Different lower case letters indicate that values in the various layers under the same colonizing organisms are significantly different; different capital letters indicate that similar layers for different colonizers are significantly different $(P<0.01)$. The bare substrate is compared with the deepest layer analysed for each colonizing organism.

\begin{tabular}{|c|c|c|c|c|}
\hline & $\begin{array}{l}\text { Biomass-C } \\
\mathrm{mg} \mathrm{kg}^{-1}\end{array}$ & $\begin{array}{l}\mathrm{CO}_{2}-\mathrm{C} \text { emitted } \\
\mathrm{mg} \mathrm{kg}^{-1} 10 \text { days }^{-1}\end{array}$ & $\begin{array}{l}\text { Dehydrogenase activity } \\
\quad \mu \mathrm{mol} \text { INTF } \mathrm{g}^{-1} \mathrm{~h}^{-1}\end{array}$ & $\begin{array}{c}\text { Dehydrogenase activity/ Biomass-C } \\
\mu \text { mol INTF } \mathrm{mg}^{-1} \text { Biomass-C } \mathrm{h}^{-1}\end{array}$ \\
\hline Bare substrate & $A 0 \pm 0$ & $A 0 \pm 0$ & $A 0.06 \pm 0.01$ & ------- \\
\hline \multicolumn{5}{|l|}{ CYANO } \\
\hline Crust layer & $A 1411 \pm 410 a$ & $A 617 \pm 149 a$ & $A 0.34 \pm 0.10 a$ & $A 0.24 \pm 0.10 a$ \\
\hline Deep layer & $B 300 \pm 122 b$ & $B 96 \pm 5 b$ & $B 0.14 \pm 0.07 b$ & $A 0.47 \pm 0.08 b$ \\
\hline \multicolumn{5}{|l|}{ DIPLOS } \\
\hline Crust layer & $B 2287 \pm 997 a$ & $B 5262 \pm 809 a$ & $B 1.02 \pm 0.24 a$ & $B 0.45 \pm 0.08 a$ \\
\hline Middle layer & $A 745 \pm 60 b$ & $A 687 \pm 150 b$ & $A 0.39 \pm 0.06 b$ & $A B 0.52 \pm 0.07 a$ \\
\hline Deep layer & $B 278 \pm 104 c$ & $C 35 \pm 19 c$ & $B 0.20 \pm 0.05 c$ & $A 0.72 \pm 0.11 b$ \\
\hline \multicolumn{5}{|l|}{ LEPRA } \\
\hline Crust layer & $B 2702 \pm 420 a$ & $B 4103 \pm 759 a$ & $B 1.05 \pm 0.16 a$ & $B 0.39 \pm 0.06 a$ \\
\hline Middle layer & $A 530 \pm 158 b$ & $A 490 \pm 170 b$ & $A 0.34 \pm 0.05 b$ & $B 0.64 \pm 0.08 b$ \\
\hline Deep layer & $B 162 \pm 37 c$ & $D 122 \pm 7 c$ & $B 0.17 \pm 0.02 c$ & $B 1.05 \pm 0.12 c$ \\
\hline
\end{tabular}


Table 3. Values of initial inorganic $\mathrm{N}$ (Total $\mathrm{N}, \mathrm{NH}_{4}{ }^{+}-\mathrm{N}, \mathrm{NO}_{3}{ }^{-} \mathrm{N}$ ) and net mineralization after 10 days incubation (values in $\mathrm{mg} \mathrm{kg}^{-1}$ ). Different lower case letters indicate that values in the various layers under the same colonizing organisms are significantly different; different capital letters indicate that similar layers for different colonizers are significantly different $(P<0.01)$. The bare substrate is compared with the deepest layer analysed for each colonizing organism.

\begin{tabular}{|c|c|c|c|c|c|c|}
\hline & \multicolumn{3}{|c|}{ Initial N } & \multicolumn{2}{|c|}{ Net mineralized $\mathrm{N}$} & $\mathrm{NO}_{3}{ }^{-}-\mathrm{N}$ \\
\hline Bare substrate & $A 14.00 \pm 1.00$ & $A 0.77 \pm 0.05$ & $A 13.23 \pm 0.90$ & $A 0.17 \pm 0.01$ & $A 2.53 \pm 0.48$ & $A-2.36 \pm 0.50$ \\
\hline \multicolumn{7}{|l|}{ CYANO } \\
\hline Crust & $A 6.62 \pm 0.82 a$ & $A 2.76 \pm 2.08 a$ & $A 3.86 \pm 1.73 a$ & $A 40.56 \pm 16.14 a$ & $A 31.43 \pm 5.59 a$ & $A 9.13 \pm 11.42 a$ \\
\hline Crust & $B 19.95 \pm 7.35 a$ & $B 13.48 \pm 6.12 a$ & $A 6.47 \pm 2.32 a b$ & $A 25.42 \pm 12.76 a$ & $A 21.27 \pm 10.73 a$ & $A 4.15 \pm 2.23 a$ \\
\hline Middle layer & $A 13.94 \pm 0.56 a$ & $A 6.57 \pm 1.97 b$ & $B 7.37 \pm 1.45 a$ & $A 20.24 \pm 9.10 a b$ & $A 0.08 \pm 2.49 b$ & $A 20.16 \pm 11.46 b$ \\
\hline Deep layer & $B 5.58 \pm 1.63 b$ & $B 2.52 \pm 0.48 c$ & $B 3.06 \pm 2.03 b$ & $C 10.08 \pm 3.82 b$ & $C 0.88 \pm 0.09 b$ & $C 9.19 \pm 3.88 a$ \\
\hline \multicolumn{7}{|l|}{ LEPRA } \\
\hline Crust & $C 30.13 \pm 7.97 a$ & $C 25.02 \pm 7.86 a$ & $A 5.11 \pm 1.96 a$ & $A 20.13 \pm 21.18 a$ & $A 13.19 \pm 17.04 a$ & $A 6.94 \pm 6.17 a$ \\
\hline
\end{tabular}


Table 4. Mean values of different coefficients related to the activity and abundance of edaphic microbiota in BCSs and in soils in different parts of Spain (in all cases the properties were analysed in a similar way). In bold type, mean values for BSCs significantly higher than for soils $(P<0.01)$; in italics and bold type, significantly lower values $(P<0.01)$.

\begin{tabular}{|c|c|c|c|c|c|}
\hline & $\begin{array}{l}\text { Crust layer of BSCs } \\
\qquad(n=9)\end{array}$ & $\begin{array}{l}\text { Tabernas soils }^{1} \\
\quad(n=5)\end{array}$ & $\begin{array}{l}\text { Sierras Béticas soils }{ }^{2} \\
\qquad(n=9)\end{array}$ & $\begin{array}{l}\text { Galician agricultural soils }{ }^{3} \\
\qquad(n=45)\end{array}$ & $\begin{array}{l}\text { Galician climax soils }^{3} \\
\quad(n=40)\end{array}$ \\
\hline Total organic $\mathrm{C}^{a}$ & $3.0 \pm 1.9$ & $0.9 \pm 0.6$ & $4.9 \pm 2.7$ & $3.2 \pm 1.0$ & $10.8 \pm 3.1$ \\
\hline $\mathrm{CO}_{2}-\mathrm{C}$ emitted $^{c}$ & $3327 \pm 2418$ & $88 \pm 26$ & $203 \pm 83$ & $161 \pm 53$ & $615 \pm 189$ \\
\hline Dehydrogenase activity $^{d}$ & $0.81 \pm 0.40$ & $0.24 \pm 0.15$ & $0.48 \pm 0.22$ & $0.28 \pm 0.08$ & $0.41 \pm 0.12$ \\
\hline$q \mathrm{CO}_{2}^{e}$ & $5.9 \pm 3.9$ & $1.3 \pm 0.8$ & $1.1 \pm 0.5$ & $3.6 \pm 1.5$ & $2.6 \pm 0.8$ \\
\hline Dehydrogenase/TOC ${ }^{f}$ & $30.3 \pm 8.2$ & $27.9 \pm 1.5$ & $12.4 \pm 5.1$ & $8.9 \pm 2.7$ & $4.8 \pm 3.5$ \\
\hline Dehydrogenase/Biomass- $\mathrm{C}^{g}$ & $0.36 \pm 0.11$ & $0.90 \pm 0.31$ & $0.78 \pm 0.29$ & $1.39 \pm 0.31$ & $0.53 \pm 0.12$ \\
\hline
\end{tabular}

', Miralles et al., 2007; ${ }^{2}$, Miralles et al., 2007b; ${ }^{3}$, Trasar-Cepeda et al., 2008.

${ }^{a} \% ;{ }^{b} \mathrm{mg} \mathrm{kg}^{-1} ;{ }^{c} \mathrm{mg} \mathrm{kg}^{-1} 10$ days $^{-1} ;{ }^{d} \mu \mathrm{mol} \mathrm{INTF} \mathrm{g}{ }^{-1} \mathrm{~h}^{-1} ;{ }^{e} \mu \mathrm{g} \mathrm{CO}_{2}-\mathrm{C} \mathrm{mg}^{-1}$ Biomass-C h$^{-1} ;{ }^{f} \mu \mathrm{mol}$ INTF g ${ }^{-1} \mathrm{TOC} \mathrm{h}^{-1} ;{ }^{g} \mu \mathrm{mol} \mathrm{INTF} \mathrm{mg}^{-1} \mathrm{Biomass}^{-\mathrm{C}} \mathrm{h}^{-1}$. 
Table 5. Correlations between the values of the hydrolase enzyme activities (Miralles et al., 2012a), Biomass-C, $\mathrm{CO}_{2}-\mathrm{C}$ emitted and dehydrogenase activity $(n=8)$.

\begin{tabular}{|c|c|c|c|c|c|c|}
\hline & Casein-protease $^{d}$ & BAA-protease $^{d}$ & Cellulase $^{e}$ & ß-glucosidase ${ }^{f}$ & Invertase $^{g}$ & Phosphomonoesterase \\
\hline Biomass- $\mathrm{C}^{a}$ & $0.95 * * *$ & $0.98 * * *$ & $0.96 * * *$ & $0.96 * * *$ & 0.47 & $0.88 * *$ \\
\hline $\mathrm{CO}_{2}-\mathrm{C}$ emitted $^{b}$ & $0.97 * * *$ & $0.94 * *$ & $0.95 * * *$ & $0.99 * * *$ & 0.27 & $0.79 *$ \\
\hline
\end{tabular}



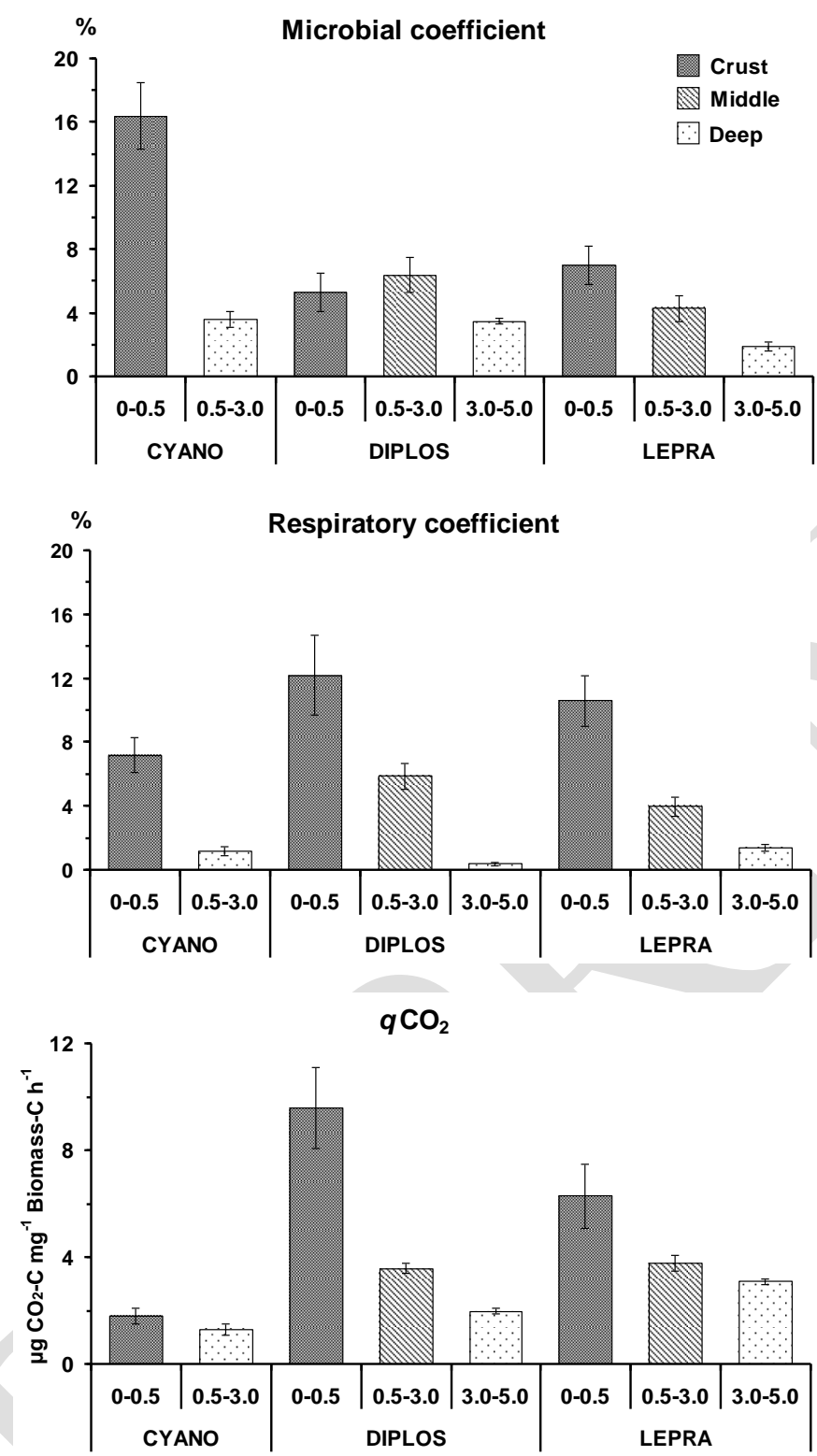

Fig. 1. Values of the microbial, respiratory and metabolic $\left(q \mathrm{CO}_{2}\right)$ coefficients in the different layers of the CYANO, DIPLOS and LEPRA BSCs. 


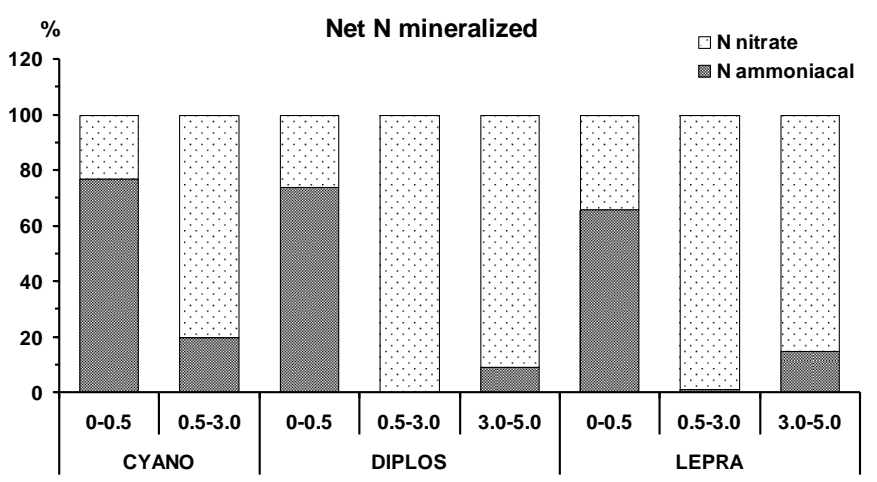

Fig. 2. Percentage distribution of potential mineralized $\mathrm{NH}_{4}{ }^{+}-\mathrm{N}$ and $\mathrm{NO}_{3}{ }^{-}-\mathrm{N}$ in the different layers of the BSCs. 

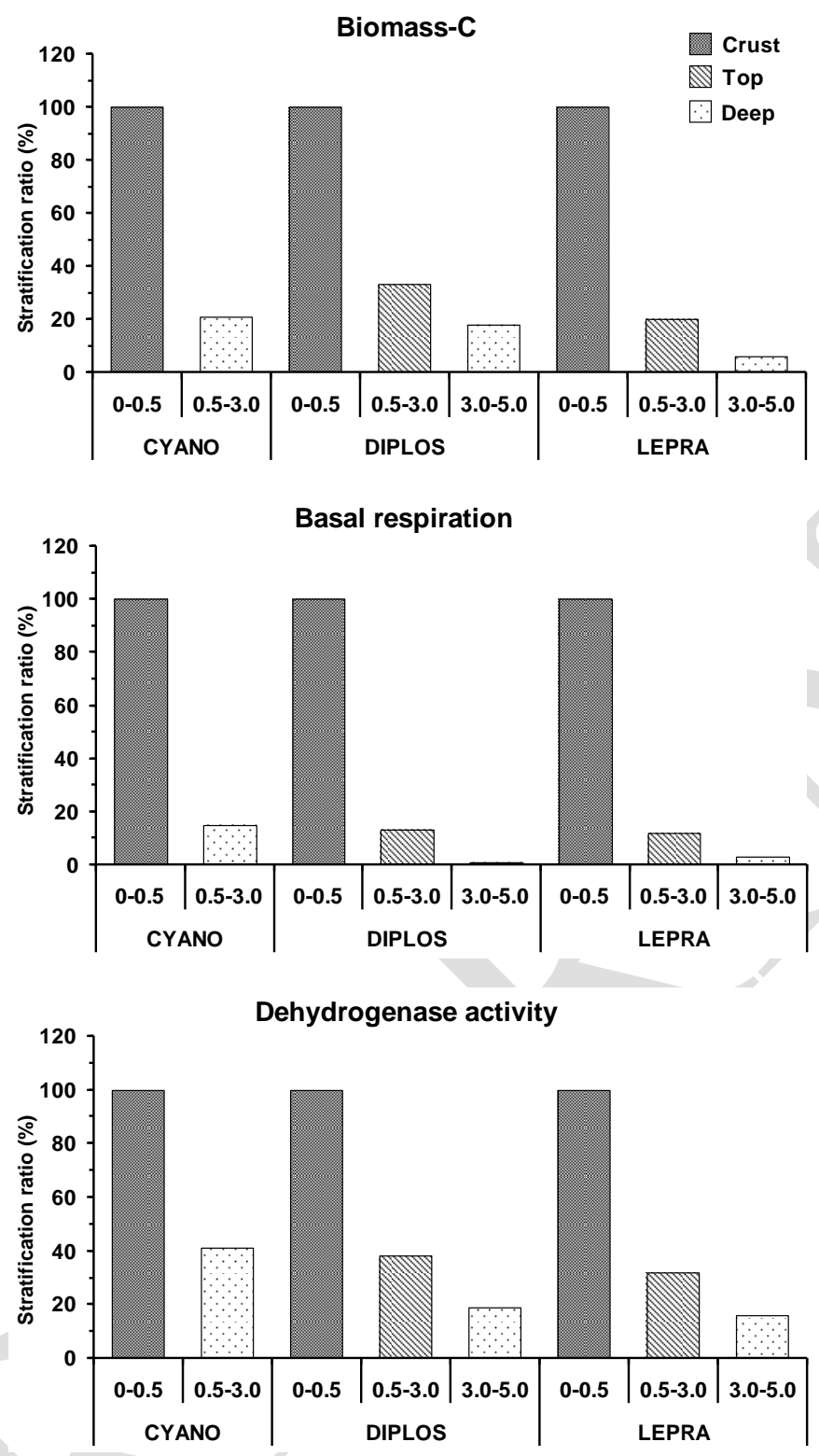

Fig. 3. Stratification ratios (the percentage value of a property at any level relative to the value in the crust layer) for the different biochemical properties in the different layers of the BSCs (crust layers are always $100 \%$ ). 

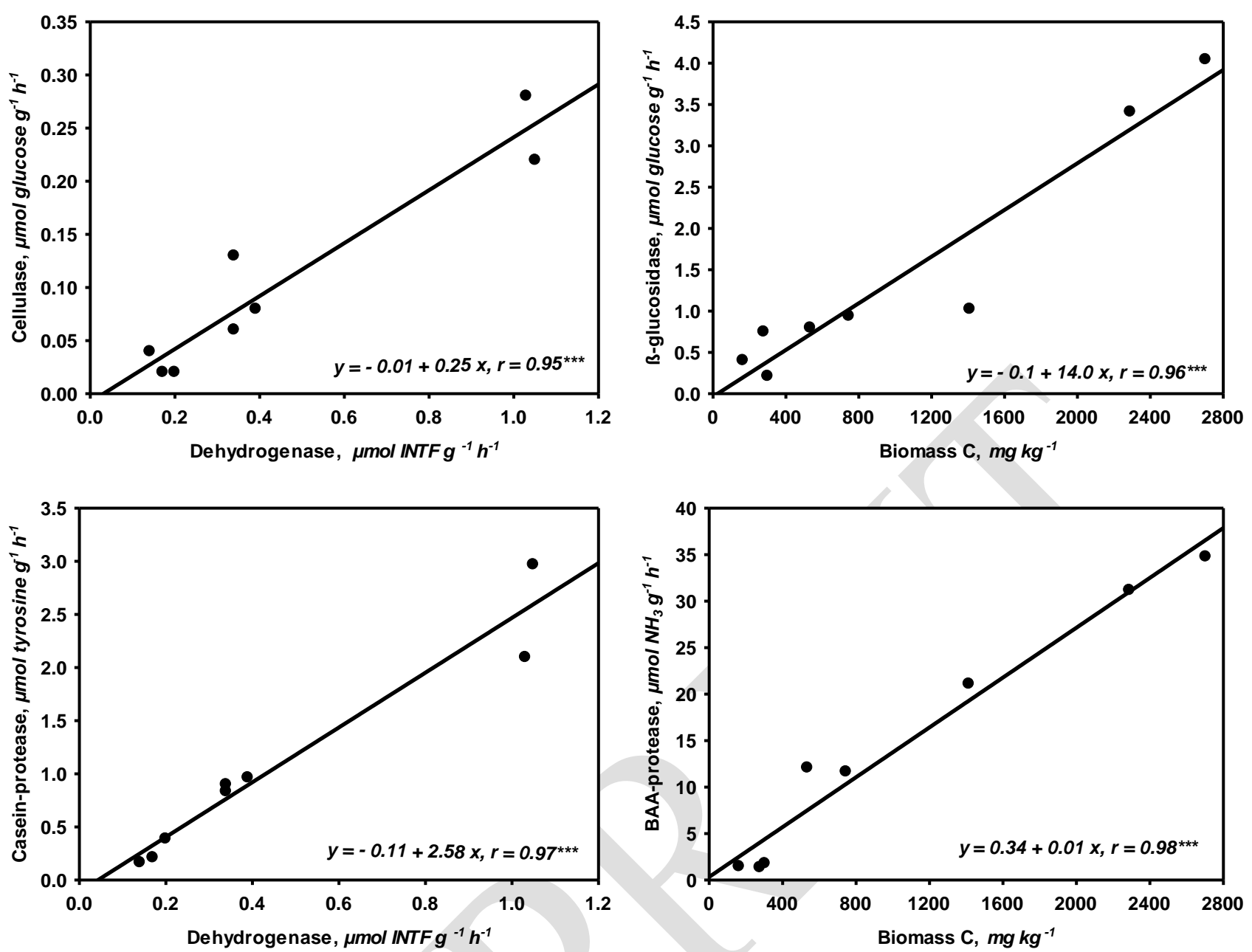

Fig. 4. Regression lines between some hydrolytic enzyme activities and biomass-C or dehydrogenase activity in all layers of the three types of BSCs studied. 